University of Warwick institutional repository

This paper is made available online in accordance with

publisher policies. Please scroll down to view the document

itself. Please refer to the repository record for this item and our

policy information available from the repository home page for

further information.

To see the final version of this paper please visit the publisher's website.

Access to the published version may require a subscription.

Authors: $\quad$ Johnston, Robert; Staughton, Roy

Article title: Establishing and developing strategic

relationships - the role for operations

managers

Year of 2009

publication:

Link to http://dx.doi.org/10.1108/01443570910957564

published

version:

Publisher None

statement: 


\title{
Establishing and Developing Strategic Relationships - The Role for Operations Managers
}

\author{
Robert Johnston, Warwick Business School \\ Roy Staughton, SHAPE International Limited
}

\author{
Professor Robert Johnston \\ Warwick Business School \\ University of Warwick \\ Coventry CV4 7AL, UK \\ email bob.johnston@warwick.ac.uk \\ Roy Staughton \\ SHAPE International Limited \\ Hereford HR2 8NT, UK \\ roystaughton@shape-international.com
}

Published in the International Journal of Production and Operations Management, vol. 29 no.

6, 2009, pp 564-590 


\title{
Establishing and Developing Strategic Relationships - The Role for Operations Managers
}

\author{
Structured Abstract \\ Purpose
}

The objectives of this paper were, firstly to identify, from the literature, the key themes in the management of strategic relationships, secondly to apply those themes to understand how exemplary organisations establish and develop strategic relationships and thirdly to determine the role of operations managers in this process.

\section{Methodology/Approach}

This empirically-based research comprised four phases; interviews with managers to identify exemplars, interviews with managers from 27 organisations, data analysis and testing of the findings.

\section{Findings}

From a theoretical point of view we have proposed a revised definition of strategic relationships. We have brought together many previously disparate elements of relationships into seven dimensions of strategic relationships. We have captured the scope and nature of exemplary relationships within each of these dimensions identifying 24 elements, and suggested the key roles for operations managers in establishing and developing their strategic business relationships.

\section{Research limitations/implications}

This research has responded to the call to help operations managers understand the skill sets required to help them establish and develop strategic business relationships. It has contributed to the growing literature on business relationships and also provided practical guidance for operations managers. The research has a number of inherent weaknesses including the interpretative nature of the analysis and that the interviews were only carried out with one party to the exemplary relationships. The focus of the research was limited to exemplary strategic relationships and the study was conducted in one sector, though a range of types of organisations were involved.

\section{Practical implications}

From a practitioner perspective the outputs from our research have been summarised into a number of guidelines which flesh out the role for operations managers looking to identify, establish, evaluate or strengthen their role in establishing and developing strategic business relationships.

\section{Originality/value of paper}

The paper provides an original and detailed perspective into the nature of strategic business relationships, irrespective of their position in the supply chain, and identifies how such relationships can be established and developed.

\section{Key words}

Supply chain relationships, business relationships, strategic relationships, nature of relationships, characteristics of relationships, dimensions of relationships. 


\section{INTRODUCTION}

Operations management (OM) used to be thought of as an internally-focused business function, concerned with manufacturing goods or delivering services with its attention on efficiency and productivity (see for example Buffa 1976, Wild 1980). Over the last 20 years the focus has shifted towards a more externally orientated, boundary spanning role, and developing closer working relationships with other parties in its supply network (see for example Fynes et al. 2005, Fitzsimmons and Fitzsimmons 2006, Howard and Squire 2007, Giannakis 2008). Over the last 40 years a significant amount has been written about such business relationships in a variety of industry sectors (see for example the work of the IMP Group, Ford et al. 2003). However, relationships and the management of relationships, with external or indeed internal partners, is something that is not often covered in the operations management literature.

Despite this, it appears to be well accepted that operations managers, and in particular purchasing and supply chain managers, have a key role to play in managing their interorganisational relationships (Giunipero et al. 2006, Monczka et al. 2004). These business relationships matter and without them organisations have difficulty accessing resources or capability, acquiring supplies, managing supply chains, solving customer problems or generating revenue (Ford et al. 2003).

While many of these business relationships will be transactional a smaller number will be strategic (see for example Henderson 1990 and Gardner and Cooper 1988). Transactional relationships have been characterised as arm's length relationships "in which the rules of the game are well specified and failure to deliver on commitments by either party can be resolved through litigation" (Henderson 1990 p8). They may involve a series of small tasks or projects, even over a long period, but in such relationships one party tends to dominate the relationship, i.e. the power and information are asymmetric (Ford et al. 2003). Strategic relationships, on the other hand, have been defined as "relationships between independent firms who share compatible goals, strive for mutual benefit, and acknowledge a high level of mutual interdependence; they join efforts to achieve goals that each firm, acting alone, could not attain easily" (Mohr and Spekman 1994, p135). They usually reflect a long-term commitment with a sense of mutual cooperation, shared risks and benefits (Henderson 1990).

Giunipero et al. (2006) asserted, as a result of their research, that the need to build strong strategic relationships was becoming more important. They explained: "Our data indicated that there are strong trends underlying this movement ... to build strategic relationships, focus on total cost and strategic cost reduction, yet being able to collaborate and integrate their processes with those of their suppliers. These managers were very clear that strong relationships drive lower costs through improved process efficiencies. Strong inter-company linkages fuel innovations which improve both quality and cost. Secondly, it appears that the supply management function will be divided into strategic and tactical areas. Tactical buyers will be more concerned with day-to-day activities, while strategic supply managers focus on building relationships and lowering total costs" (p841). They concluded that implementing these strategic initiatives will require operations managers, and supply chain managers in particular, to develop new skill sets; "The key issue is: will they be able to reach the required levels of these skills to fully realize the benefits of a more strategic approach?" (p841).

The purpose of the paper is to try to provide some insight into these skill sets by identifying the role of operations managers in establishing and developing relationships with business partners. Our focus is on strategic relationships, those long-term partnerships important for developing and sustaining competitive advantage. We are also focused on exemplary 
relationships, those outstandingly good relationships that can serve as a benchmark for organisations striving to improve their strategic relationships with key partners.

Thus we have three objectives, first to identify, from the literature, the key themes in the management of strategic relationships, second to apply those themes to understand how exemplary organisations establish and develop strategic relationships and third to determine the role of operations managers in this process. The intentions of the paper are to try to offer guidance to OM professionals who are invited or challenged to contribute to the performance of an organisation choosing to establish or develop one or more strategic relationships and also to provide a stimulus for further operations management research in this area.

The first part of the paper provides an overview of some of the extensive literature on business relationships. The second part provides a description of our method, followed by the findings. Finally we provide some suggestions for OM practitioners seeking to establish and develop strategic relationships and summarise our contribution to the literature and the limitations of this research.

\section{BUSINESS RELATIONSHIPS}

The extensive literature on business relationships comprises many different but complementary streams of research which have appeared in the somewhat diverse areas of industrial and business-to-business marketing, channel management, relationship marketing, operations management, supply chain management, logistics and purchasing (Fynes et al. 2005). Some of the key issues covered in this varied literature are summarised in Table 1.

Table $1 \quad$ Key Issues Covered in the Literature on Business Relationships

\begin{tabular}{|l|l|}
\hline \multicolumn{1}{|c|}{ Key Issues } & \multicolumn{1}{c|}{ Literature } \\
\hline Characteristics of 'successful' relationships & $\begin{array}{l}\text { Boddy and Macbeth 2000, Hutt et al., 2000, } \\
\text { Mohr and Spekman 1994, Morgan and Hunt, } \\
\text { 1994, Sleuwaegen et al. 2003 }\end{array}$ \\
\hline Cooperation and learning & Koza and Lewin 1998, Taylor 2005 \\
\hline Impact on performance and competitiveness & $\begin{array}{l}\text { Easton and Araujo 1985, Fynes et al. 2005, } \\
\text { Turnbull et al. 2002 }\end{array}$ \\
\hline Issues of power and dependence & Doz and Hamel 1998 \\
\hline Life cycles & Spekman et al. 1998, Taylor 2005 \\
\hline $\begin{array}{l}\text { Managing collaborative relationships in } \\
\text { periods of discontinuity }\end{array}$ & Coughlan et al. 2003 \\
\hline Modes of collaboration & Cousins 2005 \\
\hline Network structures of relationships & $\begin{array}{l}\text { Easton 2002, Ford et al. 2003, Lorenzoni } \\
\text { and Baden-Fuller 1995, Naudé and Turnbull } \\
1998\end{array}$ \\
\hline Partner selection & Bennett and Jayes 1998, Taylor 2005 \\
\hline Relationships as an organisational capability & Lorenzoni and Lipparini 1999 \\
\hline Risk and uncertainly in relationships & Ford et al. 2003 \\
\hline Stages in relationship development & $\begin{array}{l}\text { Dwyer et al. 1987, Ford et al. 2003, Kanter } \\
1994\end{array}$ \\
\hline Strategic relationships in supply chains & Giunipero et al. 2006 \\
\hline Success factors & $\begin{array}{l}\text { Bennett and Jayes 1998, Black et al. 2000, } \\
\text { Egan 1998, Larson 1995, Latham 1994 }\end{array}$ \\
\hline The value of long-term relationships & Bresnen and Marshall 2002, Evans and \\
\hline
\end{tabular}




\begin{tabular}{|l|l|}
\hline & $\begin{array}{l}\text { Berman 2001, Dyer 1997, Ford et al. 2003, } \\
\text { Sleuwaegen et al. 2003 }\end{array}$ \\
\hline $\begin{array}{l}\text { Theoretical frameworks including transaction } \\
\text { cost theory, political economy theory, social } \\
\text { exchange theory and resource dependence } \\
\text { theory }\end{array}$ & $\begin{array}{l}\text { Fynes et al. 2005, Robicheaux and Coleman } \\
1994\end{array}$ \\
\hline Transaction cost economics & Cousins 2005, Williamson 1986 and 2008 \\
\hline Types and nature of relationships & $\begin{array}{l}\text { Ford et al. 2003, Hăkansson and Snehota } \\
\text { 2002, Wilkinson and Young 2002 }\end{array}$ \\
\hline $\begin{array}{l}\text { Units of analysis, such as firm, dyad or } \\
\text { network }\end{array}$ & Fynes et al. 2005 \\
\hline
\end{tabular}

There have been criticisms of some of this work. For example Bresnen (2007) was concerned, in particular, that the work on 'good practice' has been "typically limited in scope as well as often heavily reliant upon supportive case studies and anecdotal evidence" ( $p$ 366). However, there is a growing body of literature that is taking a more rigorous approach, exposing some of the problems inherent in developing more collaborative business relationships, including, for example: (see also Bresnen and Marshall 2000)

- Concern for risk and cost reduction (Bresnen 1996)

- Concern over the way relationships are measured (Staughton and Johnston 2005)

- Contradictions and paradoxes of a partnering approach (Bresnen 2007)

- Issues in the early stages in development (Kelly et al. 2002)

- Problems of cultural differences (Phua and Rowlinson 2003)

- Questions about the value of business relationships (Kalwani and Narakesari 1995)

Two particular issues are pertinent to this research; types of business relationships and the characteristics of business relationships.

\section{Types of business relationships}

We use the expression 'business relationships' to cover the multitude of terms that are used to describe inter-organisational relationships both across and within supply chains, including; contracts, partnerships, alliances, strategic/global alliances, partnering, project partnering, joint ventures, and networks. There is a considerable amount of literature covering these forms, though not always agreement about what the terms mean.

Contracts, for example, are usually referred to as non-equity agreements "specifying the cooperative contributions and powers of each partner" (Stafford 1994, p67), where greater power usually lies with the purchasing 'partner'. It has been suggested that long-term and successful business relationships tend to rely less on existing contracts or even exist without formal contracts (Roxenhall and Ghauri 2004).

Partnerships, sometimes also referred to as alliances (Henderson 1990), have been defined as purposive agreements between independent firms with mutually derived goals and benefits (Mohr and Spekman 1994). Partnerships and alliances exist on a continuum from short-term to long-term. "Some alliances are no more than fleeting encounters lasting only as long as it takes one partner to establish a beachhead in a new market; others are the prelude to a full merger of two or more companies' technologies and capabilities" (Kanter 1994, p96).

Strategic alliances, sometimes also referred to as global alliances, are "voluntary arrangements between firms involving exchange, sharing, or co-development of products, technologies or services ... which can take a wide variety of forms" (Gulati 1998 p295) such 
as R\&D coalitions. Other alliances are more formal and legal arrangements such as licensing agreements or joint ventures (Taylor 2005). While strategic alliances are a logical and timely response to intense and rapid changes in economic activity, technology, and globalisation (Doz and Hamel 1998), they tend to exist as asymmetric relationships "as they often involve one party acquiring a partial stake in the other firm, thus often unequal power stakes" (Stafford 1994, p65).

Partnering, an approach in vogue in several industries in particular the construction industry, is concerned with developing closer relationships between the organisations; "Partnering involves the parties ... working together in an environment of trust and openness to realise the project efficiently without conflict" (Black et al. 2000, p423). Bennett and Jayes, following two studies in the construction industry (1995 and 1998), defined partnering as "a set of strategic objectives which embody mutual objectives of a number of firms achieved by cooperative decision making aimed at using feedback to continuously improve their joint performance" (1998 p4). The focus of such partnering is the achievement of project goals and especially the prevention of major disputes or at least developing procedures for resolving them in a timely and effective manner (Black et al. 2000, Larson 1995). Partnering can be based on a single project (project partnering or sometimes referred to as alliancing) (Bresnen 2007) "but greater benefits are available when it is based on a long-term commitment (strategic partnering)" (Bennett and Jayes 1995, p2). A fundamental requirement of strategic partnering is the development of long-term relationships between the partners (Egan 1998).

Joint ventures (JVs) are one form of alliance (Gill and Butler 2003). They can involve two or more partners "contributing resources to the formation of a new separate subsidiary, jointly owned by the partners" (Stafford 1994, p65). Joint ventures are usually formed to exploit specific opportunities by combining some resources, including specialist skills. The allocation of risk and resources shared by each partner is usually made explicit through a contract (Doz and Hamel 1998).

Finally, networks are structures of interconnecting partnerships, alliances or JVs which can take many different forms (see for example Goold and Campbell 2003). These structures are best understood as a web of relationships, a 'web' being an interdependent set of alliances (Doz and Hamel 1998). While marriage is the most commonly used analogy for other forms of business relationships (see for example Celuch et al. 2006), Doz and Hamel suggest that a better analogy for networks is 'statecraft', "in particular the past few centuries of European diplomatic and military history. Here we observe the simultaneous management of viable coalitions built on a number of bilateral [and unilateral] relationships, each with its own history" (p143).

The critical point about all of these forms is that the relationships contained within them can range on a "continuum from weak and distant to strong and close" (Kanter 1994, p98). The focus of our research are the strategic relationships towards one end of this spectrum of relationships, be they contracts, alliances, partnerships, joint ventures, or even informal relationships, within or between organisations.

\section{Confusion between strategic and transactional relationships}

From a practitioner perspective, it would appear that what are often referred to as 'strategic' relationships have been predominantly focused at the project, transactional level rather than at a strategic level, concerned with exploiting short-term arrangements rather than developing genuine long-term strategic relationships (see for example Henderson 1990, Gardner and Cooper 1988). In the construction industry, for example, many projects are, by their very nature, one-off events with sets of contractors, subcontractors, financiers, clients, designers and architects brought together for the completion of an individual development. 
Subsequent projects are likely to involve different players and even where one or two of the same organisations might be involved the individuals within the teams may well be different, making it less likely that effort will be expended by the various parties in developing or even considering strategic relationships.

Many alliances and partnerships frequently referred to as, or assumed to be, strategic are often more transactional in nature (Larson 1995). While they may involve longer-term agreements, the power relationships are heavily skewed towards one organisation with contracts and litigation, or threats of litigation, underpinning the 'relationship', despite the use of mechanisms such as pre-project team building and goal sharing activities, formulation of a project charter, the establishment of project standards and agreements about risk sharing and dispute handling (Larson 1995, Bennett and Jayes 1995 and 1998).

This limited scope of many 'relationships' is highlighted by Hutt et al. who studied an emerging strategic alliance between two Fortune 500 firms over a period of time. They found that the relationship focused more heavily on the contractual (exchange) rather than the more personal aspects of relationships:

"Yet, despite their promise, many alliances [yet they only cite one example] fail to meet expectations because little attention is given to nurturing the close working relationships and interpersonal connections that unite partnering organisations. While these personal relationships between 'boundary spanning' members, who work closely together, serve to shape and modify the evolving partnership, economic theories of exchange virtually ignore the role of people and their importance in the management of inter-organisational relationships. Surprisingly, human or people factors appear to have remained unconsidered or, at worst, dismissed in the alliance research tradition" (Hutt et al. p51).

Furthermore, in the construction industry, it has been argued that partnering, as apparently practised, is little more than good project management. Partnering tends to be a structured approach to project management rather than concerned with building strategic relationships between partners. One of Larson's respondents summarised partnering as follows:

"Partnering is a new word for being reasonable, conscientious and professional. Quite frankly I am tired of people acting like this is some great new discovery .... It's not new; it's just effective project management." (Larson 1995, p31)

In sum, many relationships are not strategic. Indeed we came across many relationships which were described by one party as strategic and by the other as transactional. However, it should be noted that such transactional relationships may well be fit for the purpose and successfully achieve the goals set for them. Further, it would appear that many organisations which claim to be engaging in strategic relationships, are acting out of a transactional mind-set. Indeed 'strategic' business relationships for them appear to be little more than mechanisms to facilitate team working for an individual task or project, or at best a series of tasks or projects, and have not been used to gain the greater potential long-term benefits from genuine strategic relationships between parties (Egan 1998).

\section{Characteristics of business relationships}

There is a rich body of knowledge capturing the many aspects of relationships, though little distinction is made between transactional and strategic relationships. Many authors have written about specific and discrete elements of 'relationships', such as trust, communication, and personal chemistry. Table 2 summarises the many characteristics of relationships that have appeared in the literature. 
Table 2 Characteristics of Business Relationships

\begin{tabular}{|c|c|}
\hline Characteristics & Literature \\
\hline Adaptability & Taylor 2005 \\
\hline Agreed performance objectives & Gill and Butler 2003 \\
\hline Commitment & $\begin{array}{l}\text { Black et al. 2000, Dyer 1997, Henderson } \\
\text { 1990, Hutt et al. 2000, Mohr and Spekman } \\
\text { 1994, Morgan and Hunt } 1994\end{array}$ \\
\hline Communication & $\begin{array}{l}\text { Black et al. 2000, Hutt et al. 2000, Mohr and } \\
\text { Spekman 1994, Morgan and Hunt 1994, } \\
\text { Kanter 1994, Celuch et al. } 2006\end{array}$ \\
\hline Conflict resolution & $\begin{array}{l}\text { Mohr and Spekman 1994, Gill and Butler } \\
2003\end{array}$ \\
\hline Contractual relations & $\begin{array}{l}\text { Cowan et al. 1992, Williamson 2008, Wuyts } \\
\text { and Geyskens } 2005\end{array}$ \\
\hline Coordination & Mohr and Spekman 1994 \\
\hline Dependence & Gill and Butler 200 \\
\hline Dispute handling & Bennett and Jayes 1995, Larson 1995 \\
\hline Flexible attitude & Black et al. 2000 \\
\hline Focusing on soft issues & Sleuwaegen et al. 2003, Stafford 1994 \\
\hline Joint problem solving & $\begin{array}{l}\text { Mohr and Spekman 1994, Staughton and } \\
\text { Johnston } 2005\end{array}$ \\
\hline Human resource practices & Taylor 2005 \\
\hline Learning capability & Koza and Lewin (1998), Taylor 2005 \\
\hline Openness & Taylor 2005 \\
\hline Organisational culture & Wuyts and Geyskens 2005 \\
\hline $\begin{array}{l}\text { Perceived (mutual) benefits from the } \\
\text { relationship }\end{array}$ & $\begin{array}{l}\text { Black et al. 2000, Henderson 1990, Morgan } \\
\text { and Hunt } 1994\end{array}$ \\
\hline Personal chemistry and compatibility & $\begin{array}{l}\text { Gill and Butler 2003, Hutt et al. 2000, Kanter } \\
1994\end{array}$ \\
\hline Persuasion & Mohr and Spekman 1994 \\
\hline Problem solving - appraisal processes & Celuch et al. 2006 \\
\hline Staff attitude and professionalism & Staughton and Johnston 2005 \\
\hline Trust & $\begin{array}{l}\text { Blois1999, Dyer 1997, Gill and Butler 2003, } \\
\text { Hutt et al. 2000, Johnston et al. 2004, Mohr } \\
\text { and Spekman 1994, Morgan and Hunt } 1994\end{array}$ \\
\hline $\begin{array}{l}\text { Understanding each other's organisational } \\
\text { culture and values }\end{array}$ & $\begin{array}{l}\text { Morgan and Hunt 1994, Sleuwaegen et al. } \\
2003 \text {, Stafford } 1994\end{array}$ \\
\hline $\begin{array}{l}\text { Understanding each other's roles, goals, } \\
\text { resources and structures }\end{array}$ & $\begin{array}{l}\text { Black et al. 2000, Boddy and Macbeth } 2000 \text {, } \\
\text { Stafford } 1994\end{array}$ \\
\hline $\begin{array}{l}\text { Understanding each other's strategic } \\
\text { objectives }\end{array}$ & Sleuwaegen et al. 2003, Stafford 1994 \\
\hline Understanding each others expectations & Celuch et al. 2006 \\
\hline Working style & Staughton and Johnston 2005 \\
\hline
\end{tabular}

One organisation which has tried to integrate some of these characteristics into a single framework is The Reading Construction Forum. Their reports set out the notion of first, second and third generation partnering (Bennett and Jayes 1995 and 1998). The first generation revolved around the use of project teams with mutual objectives, open decision making and problem resolution and a focus on continuous improvements. The more sophisticated second generation approach built on the first generation and focused on a more strategic approach building on the 'seven pillars of partnering' which include strategy, membership, equity, integration, benchmarks, project processes and feedback. The seven pillars provide a helpful practitioner guide suggesting the key characteristics of strategic 
relationships. However, they do not appear to include all the characteristics captured in Table 2 nor do they provide a detailed understanding of the scope of strategic relationships or the ways in which they can be created and strengthened, which is the objective of our work. They also do not clarify the distinction between strategic and transactional relationships.

In order to meet our first objective of identifying the key themes in the management of strategic relationships and to provide a more complete structure for our research we would like to suggest that there are seven key dimensions of relationships which seem to capture all the characteristics from the literature: partner selection, nature of the contract, understanding each other, interpersonal relationships, way of working, dealing with problems, performance management. Table 3 below provides our initial definitions of these dimensions and shows the characteristics from the literature associated with each. The first two dimensions are primarily concerned with establishing relationships and the last five appear to be concerned with developing (existing) relationships.

Table 3 Dimensions of Relationships

\begin{tabular}{|l|l|l|}
\hline \multicolumn{1}{|c|}{ Dimension } & \multicolumn{1}{|c|}{ Definition } & \multicolumn{1}{c|}{ Characteristics } \\
\hline Partner Selection & Who you choose to work with & $\begin{array}{l}\text { strategy, membership, } \\
\text { equity, organisational culture }\end{array}$ \\
\hline Nature of Contract & $\begin{array}{l}\text { Impact of the contract on the } \\
\text { relationship and vice versa }\end{array}$ & contractual relations \\
Understanding each Other & $\begin{array}{l}\text { Understanding each others' } \\
\text { expectations and perceptions }\end{array}$ & $\begin{array}{l}\text { mutual objectives, } \\
\text { dependence, perceived } \\
\text { benefits, partner } \\
\text { expectations }\end{array}$ \\
\hline Interpersonal Relationships & $\begin{array}{l}\text { One on one relationships at } \\
\text { work and socially }\end{array}$ & $\begin{array}{l}\text { integration, commitment, } \\
\text { communication, flexible } \\
\text { attitude, soft issues, personal } \\
\text { chemistry, persuasion, } \\
\text { attitude and professionalism, } \\
\text { trust, working style }\end{array}$ \\
\hline Way of Working & $\begin{array}{l}\text { Relationships at an } \\
\text { organisational level } \\
\text { coordination, trust, culture }\end{array}$ \\
\hline Dealing with Problems & $\begin{array}{l}\text { Dealing with and learning } \\
\text { from problems }\end{array}$ & $\begin{array}{l}\text { conflict resolution, dispute } \\
\text { handling, joint problem } \\
\text { solving, appraisal processes }\end{array}$ \\
\hline Performance Management & $\begin{array}{l}\text { Using measures to drive } \\
\text { action and improvement }\end{array}$ & $\begin{array}{l}\text { benchmarks, feedback, } \\
\text { agreed performance } \\
\text { objectives }\end{array}$ \\
\hline
\end{tabular}

\section{RESEARCH METHODOLOGY}

In order to meet our second and third objectives; to apply the themes (dimensions) to understand how exemplary organisations establish and develop strategic relationships and to determine the role of operations managers in this process, we identified some organisations, and the individuals within them, which were recognised to be operating 'real' and 'exemplary' strategic relationships. By real we mean long-term relationships that exist within and between projects and activities, with a high sense of mutual cooperation, with shared risks and benefits and high interdependence; by exemplary we mean relationships and players that are recognised by their peers as leading practitioners in the field of 
developing strategic relationships with other organisations, irrespective of their position in the supply chain.

The research on which this paper is based lasted over two years and formed part of a wider piece of work running for five years in the construction industry. The study was supported and facilitated by a major construction company in the UK, part of one of the world's leading construction groups. The company has expertise in construction, development of commercial and residential projects and public-private partnerships. It has a reputation for working closely with its clients, and managing its projects in an integrative way together with its clients, partners and supply chain. We were able to use their contacts in a wide range of associated sectors to advantage to identify organisations with reputations for exemplary relationships and gain access to executives within them.

Mindful of the potential impact of our interventions we chose a methodology that would reflect the positive, exemplary, aspirations of the research, rather than adopt a problembased one. Our approach was based on Appreciative Inquiry (Cooperrider and Srivastva 1997, Cooperrider and Whitney 2005). In contrast to deficit-based theories of change which seek out weaknesses and limitations, Appreciative Inquiry (Al) deliberately enquires into those moments and episodes when experiences have been at their best, and their strongest. It is concerned to learn from high-point experiences and to discern those factors and circumstances that contributed to such experiences.

The study comprised four phases.

In the first phase one-on-one interviews were held with a convenience sample of 24 senior managers across the sponsoring company to identify 'exemplars' in the area of strategic business relationships. The interviewees were chosen because they were responsible for overseeing one or more major projects and also for managing the relationship with one or more key clients. The purpose of this phase was to identify organisations and individuals within them that could be interviewed in phase two. More than fifty exemplar organisations, allied to the construction industry - but not necessarily construction companies - and the key individuals within them were identified.

In phase two, thirty of these organisations were invited to contribute to the research. They were chosen to provide a cross section of inputs from along the supply chain. Twenty seven agreed to participate. The exemplar organisations were a mixture of clients (including government bodies), partners (including consultants), financiers, designers, contractors and sub-contractors. These are summarised in Table 4. Videotaped interviews were held with one or more senior managers with operational responsibility for the relationships from each of the exemplar organisations to draw out the essence of what made their organisations successful and admired for their strategic business relationships.

Table $4 \quad$ The Exemplar Organisations

\begin{tabular}{|lc|}
\hline Type of Organisation & Number \\
\hline Architect & 1 \\
Client & 8 \\
Consultant & 5 \\
Contractor & 7 \\
Financier & 1 \\
Joint venture partner & 2 \\
Sub contractor & 3 \\
\cline { 2 - 2 } & 27 \\
\hline
\end{tabular}


All the interviewees were senior managers and each interview lasted around ninety minutes. The interviews were structured around seven main questions, with sub questions crafted in appreciative language aimed at identifying how these exemplar organisations established and developed strategic relationships:

1. Which of the seven dimensions are important in establishing strategic relationships?

2. What do you pay particular attention to when establishing strategic relationships? What do you do? How do you do it?

3. What underpinned the creation of the best relationships? What really made a difference?

4. Which of the seven dimensions are important in helping develop strategic relationships?

5. What do you pay particular attention to when developing strategic relationships? What do you do? How do you do it?

6. What underpinned the development of the best relationships? What really made a difference?

7. When relationships are at their best, such as when they are at their most productive, or when they are adding greatest value, or when they are at their most memorable - what is going on, what do you notice, what is making the difference?

Around forty five hours worth of material was collected amounting to several hundred statements which captured the respondents' answers to the questions.

Phase three involved the analysis of the data, independently by the two researchers, using open, intuitive and selective coding. The researchers separately summarised the comments into key words and phrases and identified potentially important clusters. Then, coming together into a conversational mode (Shaw 2002) they made sense of the emerging patterns. After several iterations of this process of sorting and sifting, several elements of the seven dimensions emerged and the roles associated with them.

In phase four the emerging material was tested for legitimacy, construct validity and usefulness. Discussions to explore and test the findings were held initially with the board of directors of the sponsoring company and subsequently with a total of around one hundred senior managers from the same organisation in six groups of around 15 to 20 in each. The findings were further tested using scenarios provided by the researchers and examples of existing relationships recalled by the directors and managers. Minor adjustments were made as a result of this process, for example the managers preferred the term 'nature of the contract' instead of our initial suggestion 'contract related issues'. They also encouraged us to create more elements for each dimension so that they were better able to understand and, at some point in the future, evaluate and measure each dimension.

\section{FINDINGS}

Our research has identified three components of exemplary performance in establishing and developing strategic relationships. First, our research provided evidence to suggest that all of the seven dimensions of relationships were important to the exemplars, although not every exemplar excelled in all areas. Second, we identified a small number of aspects within each dimension - we have called them 'elements' - which were the focus of special and ongoing attention on the part of exemplars. And third, we captured the roles of these 
exemplar managers in establishing and developing, i.e. how they went about it for each of the elements.

\section{Dimensions of Strategic Relationships}

All seven dimensions were reported as being important. However, the first two were key to establishing relationships and the last five critical to developing relationships. This section summarises the views of the exemplars of each dimension illustrating them with a selection of quotes from our interviews.

\section{Partner selection}

"We are very careful to select who we want to work for and who we want to work with."

This dimension was seen to be critical to the 'establishing' stage of every relationship studied. It reflects the attention paid by exemplars, irrespective of where they sit in the supply chain, to the importance of choosing their business partners. We were told of clear policies to consciously select rather than passively accept business partners.

The term 'partner' was not used to suggest any particular affinity with the term 'partnering'. Neither did it imply only provider (for example contractor) selection. It had validity up, down and across the supply chain. Up involved client selection; down covered suppliers, contractors, providers of professional services and consultants and across applied to sister companies and joint venture partners.

\section{Nature of the contract}

"The contract should support the spirit of the relationship not get in the way."

This dimension is concerned with the impact that the contract established between the two parties would have on a new or an on-going relationship.

Our exemplars focussed their attention on the spirit of the contracts they drew up rather than their detailed content. They did not infer that any particular form of contract was preferable to another but were adamant that contracts should support the spirit of the relationship they aspired to. On the whole they tended to categorise fixed-price contracts with penalties as fundamentally adversarial whereas cost reimbursable, open book, 'shared pain and gain' contracts were seen as helping the partners to focus on joint working and resolution of issues for the benefit of both parties.

They also recognised that a satisfactory and fruitful current relationship would influence the type of contract that the partners felt to be necessary and appropriate in the future. At all times the exemplar organisations would make genuine efforts to "put the contract away in the drawer" and work in a more collegiate way, even if things went wrong.

Together with partner selection this dimension was reported as setting the scope for a relationship at the outset, either encouraging and enabling the actions and behaviours of the players, or confining and constraining them. Both dimensions have a great impact at the 'establishing' stage and continue to exert an influence throughout the life of a relationship.

The remaining five dimensions although they may in some circumstances have a role to play when a relationship is being established, typically deliver their greatest influence throughout the development of a relationship. 


\section{Understanding each other}

"It's about each party knowing what turns the other party on."

This dimension reflects the need for each party to a relationship to understand the expectations and perceptions of the other.

The interviewees stressed their desire for two-way, parity-type, long-term relationships. To do this they believed that each party needed to have clarity around the other's business aspirations and their business drivers. Equally importantly they needed an understanding of each others' expectations for, and perceptions of, the relationship.

"It's about developing a clear understanding of the business drivers of each party and a realisation that each party should provide added value and that each party has a right to make a decent return. Understanding each other's business takes a lot of time and effort, and you have to invest a lot of time and resource into this."

The exemplar organisations set up clear mechanisms to achieve this understanding of each other, both at a business-to-business level, through series of meetings and facilitated discussions and also through their joint contribution to industry fora on particular subjects, such as health and safety.

\section{Interpersonal relationships}

"There are some people you just get on better with."

This dimension exerts its greatest influence on the development of relationships, though it can in a limited form have an input to the establishment of a new relationship. It captures the emphasis our exemplars placed on the way that the key players in a relationship interacted when they were operating 'one-on-one'. It embraces a close and positive approach to building one-on-one relationships and extends into the social arena - theatre, dinner or sporting occasions.

"There is a degree of marriage in any project. Projects are more about soft issues than hard issues. There is a natural chemistry about relationships and businesses don't put nearly enough effort into this."

\section{Way of working}

"We have always recognised the value of working well together."

This dimension captures and categorises those aspects of a relationship that are more institutional than individual. It refers to the way that the players in a relationship interact and develop their relationships at a broader, organisational level. It reflects such issues as culture, behaviour, attitude and trust, recognising the huge contribution to the quality of a relationship that derives from its softer attitudinal, behavioural aspects.

"Two plus two does equal five. When you visit us you will see all the people from both sides of the relationship in one room. We try to make them interchangeable. We are trying really hard to develop integrated teams. They are the delivery team for the project, irrespective of who they work for. The monthly report, for example, is one document put together jointly by the team, not composed separately by each party."

\section{Dealing with problems}


"Ultimately, the proof is how the relationship holds together when things go wrong."

Dealing with problems concerned the way the two parties created agreed processes for dealing with problems, before they arose. It is another example of a dimension that has some importance at the 'establishing' stage of a relationship but greatest impact on the way a relationship develops. Accepting the inevitability of the occurrence of problems and the destructiveness of acrimonious blame placing, the key concern expressed by respondents was the need to be prepared and to set up mechanisms to learn from problems.

Several of the interviewees described the 'acid test' of a business relationship as 'learning from operational problems to strengthen the relationship'. There was a clear view that learning from problems not only improved operational activities but also strengthened and developed the relationship.

"Once things go wrong there is a tendency for organisations to revert to the adversarial approach."

“We place great emphasis on references. We don't just look at how they behave when things are going well. The good times are the easy times."

The exemplars focused on moving from a blame culture to a jointly developed culture concerned with learning from mistakes.

"We are trying to take away the ability of people to blame each other. It's dangerous to say that we try and make everyone responsible for everything, but the approach is that everyone is responsible for the project as a whole."

"If you have gone through a difficulty together you are inherently better next time around - you have learned something."

\section{Performance management}

"Just having a gut feel about the relationship is not enough."

This dimension exerts a major influence on the development of a relationship. It takes the debate about the performance of the relationship beyond merely measuring it - exemplars were using metrics of their relationship to drive action and improvement. Our respondents stressed that both parties should contribute to the decisions on what should be measured and how it should be measured. The ideal appeared to be a mix of business measures and measures of the relationship - both hard and soft.

The respondents appeared to want to move much further than most organisations would typically travel. Strong, valuable, lasting and fruitful relationships would not evolve, they said, until both parties paid attention to the responses that the measures called for. The need they described was for the players in a relationship to jointly measure and manage both the soft as well as the hard elements of it.

This dimension was not as widely practised or as fully developed as the others. Our interviewees described performance management as being at the centre of managing and developing their relationships, though several identified difficulties in getting good measures of the 'softer', more interpersonal and cultural aspects of their relationships to complement the operational and financial measures. 
"Measurement is the Holy Grail. It's not easy to find good measures for the things that you can put pound notes signs against, let alone the soft issues."

This dimension goes somewhat beyond simple recognition of a need and extends into the joint development of measures of both the contract and the relationship, supported by mechanisms to allow the parties to jointly assess, discuss and develop their relationship.

\section{Elements of Strategic Relationships}

Within each of the seven dimensions of strategic relationships we identified several aspects which we have called 'elements' of strategic relationships - that reveal particular areas of focus exhibited by the exemplar managers as they worked to establish and develop strategic relationships with their partners. As before, we have provided a selection of quotes from our interviews to illustrate our findings.

\section{Partner selection}

Four separate elements of this dimension became apparent:

Business Fit - Managers reported that they looked for a mutual fit between their own aspirations, objectives, vision and culture and those of the businesses they would work with.

Mind-set - The interviewees saw compatible or matching mind-sets as essential for longterm relationships and had clearly thought through and articulated views of the appropriate mind-set for their partners. Once selected they would commit to their partners through good or ill - "this relationship is for life not just for Christmas" - and they looked for a reciprocal commitment.

"Unless they fail we carry on with them. And even if they do fail, it's only if we can't pick them up that we don't continue with them."

Selection Criteria - The senior managers had carefully developed and detailed sets of selection criteria covering cultural and behavioural issues. The more commonly encountered technical and commercial criteria tended to be seen as little more than qualifiers or givens in the selection process. The final choice was made on a rigorous comparison of values, ethos and culture driven by a desire to identify the partner with whom the organisations felt they could best develop a relationship:

"We try to find the company we can get on with best, rather than the company that gives us the sexiest design or the best price."

"You need to identify which contractor you want to work with long-term; which one is accepting the philosophy you are trying to deliver."

Selection Process - The exemplar organisations had clear and frequently well-published aspirations for the type of partner they sought. They had researched and documented selection guidelines, for both the hard and the soft aspects of their relationships and they employed clear and agreed processes for identifying, approaching and engaging with a potential partner.

\section{Nature of the contract}

Our research revealed four key elements to this dimension: 
Fit - Fit between the contract and the relationship was seen as vital in supporting the alignment of strategies, goals, aspirations and desired culture. It was exemplified by contracts which supported and served the relationship over time, encouraging flexibility, transparency and continuity. The obvious passion for parity established at the selection stage was continued here and interviewees aspired to mutually developed, rather than imposed contracts.

Impact - For the leading organisations the contract helped deliver success. It didn't stand in the way or conflict with the spirit of the relationship. It modelled openness, trust and collaboration, not just between the two partners but also further up and down the supply chain.

Risk - In the exemplar relationships we explored, openness was thought of as turning risk into a positive feature of the relationship. Where it was mentioned at all risk was allocated to the party most able to manage it.

Detail - The interviewees described their contracts as being typified by their light touch and broad headers. Contracts established a way of working along with fora and agendas for piloting the relationship. At their best they specified what a successful relationship would look like and provided detailed examples on behavioural issues sometimes supported by appropriate soft measures.

\section{Understanding each other}

The exemplars seemed to operate this understanding at three levels:

Individual level - The interviewees encountered during our research had processes which jointly captured and built upon expectations and perceptions of the individuals with whom they worked in the 'partner' organisation. Consequently both parties appeared to know the factors which would 'wow' their partners as well as having an understanding of what would 'get up their noses'.

Business level - Command of this element was demonstrated by businesses that had fully aligned their intentions, their visions, their goals and their fiscal plans. The two parties understood each others' decision making processes - why, what, who and how - and they had a finely detailed understanding of each others' drivers.

Process - Parties to exemplar relationships appeared to work very hard to understand what was important for the other business. They were continually updating each other about new developments and ideas. They had regular, joint reviews of expectations and perceptions underpinned by discussions and analysis driven by joint measurement routines. Interestingly this closeness didn't appear to stifle innovation and creativity. On the contrary unplanned opportunities were positively encouraged.

\section{Interpersonal relationships}

Our research uncovered three elements of interpersonal relationships:

Approach - In exemplar relationships the appropriate or approved style of behaviour was modelled from the top and the long-term nature of the relationship ensured that it became embedded across both organisations. Over time interpersonal styles came to exhibit an obvious and natural chemistry and a complete absence of posturing, supported by a shared passion for the relationship between individuals at all levels. Because they had mutual trust and respect people appeared to be comfortable when disagreeing, they were empathetic 
and always tried to go the extra mile for each other. Above all they saw interpersonal relationships as something to be enjoyed - a source of fun.

Communications - The interviewees believed that communications should always be totally open and honest. Meetings were regular, planned, balanced and two-way, both in the construction and the pursuit of the agenda. Over time the players developed and spoke a shared language while perfecting the ability to adapt their style to suit different individuals and circumstances.

Process - The exemplar organisations held regular and ongoing reviews of their meetings, paying attention to not only content but also the style and the process. At this level trust is built upon dialogue, so people worked hard at perfecting their soft skills and checked continuously for miscommunication and misinterpretation.

\section{Way of working}

There appeared to be four elements that need to be carefully aligned and which act as the cornerstones of success for this dimension:

Drivers - The interviewees put effort into clarifying and disseminating the drivers for their preferred way of working. They described their relationships as 'journeys' and 'sources of competitive advantage' and they worked on them at all levels together - often off-line. They regarded technical and commercial expertise as givens and had a clear focus on success and finding elegant solutions to the challenges they faced.

Culture - The exemplar organisations paid particular attention to behaviour describing their ways of working as mature, invigorating, evolving, adaptable, fair, optimistic and interdependent. Both parties in the relationships were said to be avid listeners and learners; never letting each other down. Consequently team confidence in the relationship was high enough to make it acceptable for partners to say 'no' to each other. There appeared to be total openness and transparency and the parties worked together in an integrated, collaborative way.

Impact - To the external observer, the objective of the exemplar organisations was to make it appear as though the partnerships were just one single company, rather than two. The impacts of these symbiotic ways of working were clearly recognised as sources of competitive advantage, which manifested themselves as predictability of the classic hard deliverables like timeliness, cost and quality and also, and increasingly more importantly, as softer benefits like commitment, trust, coordination and compatibility.

Process - The interviewees had a passion for and expertise in the processes which supported and shaped their preferred ways of working. They expected the continuing involvement of all stakeholders in the relationship and had processes in place to invest in relationships between as well as within contracts. Although contacts appeared to be matrixed at all levels, the exemplar practitioners also had nominated relationship managers in place.

\section{Dealing with problems}

The exemplars recognised three separate elements of this dimension.

Approach - The interviewees reported that they saw problems as opportunities to learn and develop relationship skills. Consequently they tried to focus on solutions and the way they were handled, rather than the problems and their causes. Issues were dealt with comfortably 
and naturally through joint exploration of possibilities and alternatives, in an atmosphere that was free from point-scoring.

Impact - The impact of this approach was that solutions tended to lead to better outcomes and increased value for both parties. The key players learned from good news as well as bad, no-one felt alone and the jointly constructed outcome usually left the relationship in a stronger place.

Process - Partners in the exemplar organisations had processes in place to ensure that problems became everyone's top priority. They had organisationally-based learning approaches, accompanied by honest post-mortems, with jointly developed methods of airing issues, capturing, holding and disseminating solutions and sharing good practice.

\section{Performance management}

The organisations encountered in our research were notable for their attention to three separate elements of this dimension:

Emphasis - The interviewees went beyond a simple focus on process issues, holding a firm conviction that 'what matters gets measured'. As a result, two-way reviews of performance were held regularly against predetermined, mutually derived criteria. These were supported by regular examination of performance against importance to refocus their efforts.

Mix - The respondents took conscious decisions about the mix of measures they used, taking great care to embrace softer, behavioural issues such as perceptions and attitude as well as the more conventional harder deliverables. In those instances where suitable metrics of the relationship were not readily forthcoming exemplars were actively seeking surrogates for improved performance.

Process - The interviewees reported that they had customised processes, clearly defined and well proven tools for measurement and that they used the measures to jointly and continuously assess and develop the relationship.

Soft measures were used not only to monitor the health of the relationship, but also in the recruitment, development and promotion of staff. An interesting trend was also seen to be emerging, with interviewees interested in understanding and quantifying the tangible benefits of their symbiotic arrangements.

Table 5 provides a summary of the elements associated with each dimension and some illustrative quotes.

Table $5 \quad$ Elements of Strategic Relationships

\begin{tabular}{|l|l|l|}
\hline Dimension & Elements & \multicolumn{1}{|c|}{ Illustrative quotes drawn from Exemplar interviews } \\
\hline $\begin{array}{l}\text { Partner } \\
\text { Selection }\end{array}$ & Business fit & $\begin{array}{l}\text { - We have clear aspirations for the right type of partner and type of } \\
\text { project; we look for a mutual fit of aspirations, objectives, vision, } \\
\text { values and culture. }\end{array}$ \\
\cline { 2 - 3 } & Mind set & $\begin{array}{l}\text { - A long term relationship is essential; we commit to each other for } \\
\text { good or ill. }\end{array}$ \\
\cline { 2 - 3 } & Criteria & $\begin{array}{l}\text { - We explore technical, commercial, cultural and behavioural } \\
\text { issues and select on values, ethos and culture. }\end{array}$ \\
\cline { 2 - 3 } & Process & $\begin{array}{l}\text { - Our selection guidelines are supported by rigorous tools and } \\
\text { processes. }\end{array}$ \\
\hline Nature of the & Fit & - The contract must be parity-based, mutually developed and \\
\cline { 2 - 3 }
\end{tabular}




\begin{tabular}{|c|c|c|}
\hline \multirow[t]{4}{*}{ Contract } & & support and serve the relationship over time. \\
\hline & Impact & $\begin{array}{l}\text { - It should enable collaboration up and down the supply chain and } \\
\text { deliver transparency, flexibility and success. }\end{array}$ \\
\hline & Risk & $\begin{array}{l}\text { Risk is always allocated to the party most able to manage it; we } \\
\text { find that transparency and openness turn risk into a positive } \\
\text { feature. }\end{array}$ \\
\hline & Detail & $\begin{array}{l}\text { - We favour a light touch with broad headers and we take care to } \\
\text { specify both success and behaviour with agreed measures. }\end{array}$ \\
\hline \multirow[t]{3}{*}{$\begin{array}{l}\text { Understanding } \\
\text { each Other }\end{array}$} & Individual level & $\begin{array}{l}\text { - We make the effort to get to know each other's 'wow' factors and } \\
\text { what will 'get up the other guy's nose'. }\end{array}$ \\
\hline & Business level & $\begin{array}{l}\text { - We have a detailed understanding of each others' drivers and } \\
\text { decision making processes - why, what, who \& how. }\end{array}$ \\
\hline & Process & $\begin{array}{l}\text { - We set up regular, joint reviews of expectations and perceptions } \\
\text { and work hard to understand what is important for each other. }\end{array}$ \\
\hline \multirow[t]{3}{*}{$\begin{array}{l}\text { Interpersonal } \\
\text { Relationships }\end{array}$} & Approach & $\begin{array}{l}\text { - A natural chemistry and shared passion free from posturing is } \\
\text { embedded and modelled from the top. }\end{array}$ \\
\hline & Communications & $\begin{array}{l}\text { - We see dialogue as vital and encourage it through regular, } \\
\text { planned, balanced and two-way meetings. }\end{array}$ \\
\hline & Process & $\begin{array}{l}\text { - We work hard at developing soft skills and continually check for } \\
\text { miscommunication \& misinterpretation. }\end{array}$ \\
\hline \multirow[t]{4}{*}{$\begin{array}{l}\text { Way of } \\
\text { Working }\end{array}$} & Drivers & $\begin{array}{l}\text { - We see our relationships as sources of competitive advantage; } \\
\text { we focus on finding smart successful solutions together. }\end{array}$ \\
\hline & Culture & $\begin{array}{l}\text { We describe it as invigorating, evolving, adaptable, fair, } \\
\text { optimistic, interdependent, open and transparent; driven by } \\
\text { integrated and collaborative working at all levels. }\end{array}$ \\
\hline & Impact & $\begin{array}{l}\text { - We have measured a marked improvement in predictability; a } \\
\text { clear source of competitive advantage. }\end{array}$ \\
\hline & Process & $\begin{array}{l}\text { - We set up totally matrixed contacts at all levels and we invest in } \\
\text { relationships both between and within contracts. }\end{array}$ \\
\hline \multirow[t]{3}{*}{$\begin{array}{l}\text { Dealing with } \\
\text { Problems }\end{array}$} & Approach & $\begin{array}{l}\text {-We see problems as opportunities to learn and develop through } \\
\text { joint exploration of issues and alternatives. }\end{array}$ \\
\hline & Impact & $\begin{array}{l}\text { - We learn from good news as well as bad; the solutions we } \\
\text { develop together lead to better outcomes and value for all. }\end{array}$ \\
\hline & Process & $\begin{array}{l}\text { - Problems become everyone's top priority; issues are aired, } \\
\text { solutions are disseminated and good practice is shared. }\end{array}$ \\
\hline \multirow[t]{3}{*}{$\begin{array}{l}\text { Performance } \\
\text { Management }\end{array}$} & Emphasis & $\begin{array}{l}\text { - What matters is measured, analysed and acted upon using two } \\
\text { way reviews built around mutually derived criteria }\end{array}$ \\
\hline & Mix & - We measure behaviours as well as deliverables \\
\hline & Process & $\begin{array}{l}\text { - We use tailor-made tools to jointly measure, assess and develop } \\
\text { our relationships. }\end{array}$ \\
\hline
\end{tabular}

\section{Establishing and Developing Strategic Relationships}

The existing literature has identified a myriad of issues underpinning business relationships (summarised in Table 2). The Reading Construction Forum made an initial attempt to provide some structure proposing, though not testing, their seven pillars of partnering for use in the construction industry (see Bennett and Jayes 1995 and 1998). However these do not appear to capture the breadth of issues identified in the wider literature. This study has developed a more comprehensive framework categorising the issues into seven key dimensions for establishing and developing business relationships which we would suggest are less industry specific.

We have then tested the dimensions with senior managers responsible for managing key relationships. Furthermore we found that two dimensions are primarily concerned with establishing relationships and five with developing relationships. By focusing on exemplar 
relationships we have expanded our managerial understanding of these dimensions to create elements that, in the following section, allows us to propose the roles for operations management in establishing and developing their key strategic relationships. In so doing we have attempted to respond to the call for the need for operations manager to develop new skill sets in establishing and developing strategic relationships (Giunipero et al. (2006).

Our discussions with the managers in these exemplary relationships captured how they went about establishing and developing their exemplary strategic business relationships using the seven dimensions as a framework:

\section{Partner Selection}

Most of the respondents were involved in the process of selecting prospective strategic partners. They made a point of exploring technical, commercial, cultural and behavioural issues rigorously. They appeared to look for a mutual fit of aspirations, objectives, vision, values and culture, and check out the compatibility between the mind-sets of the two businesses.

\section{Nature of the Contract}

In their preparation of the contracts the interviewees tried to ensure that they were worded in a way that supported the spirit of the relationship they were looking to create and that they would enable collaboration over time. They used a 'light touch' with jointly developed broad headers specifying both success and behaviour - with agreed measures - to try to encourage flexibility and success. Finally they ensured that operational risk was allocated to the party most able to manage it.

\section{Understanding each Other}

As the relationships developed, the interviewees set aside time to understand, articulate and jointly agree each other's expectations for the operation and perceptions of the relationship; looking to understand each others' drivers and the decision making processes at both an operations and a business level: making the effort to get to know each other's 'wow' factors and what will 'get up the other guy's nose' both in terms of operational performance and behaviour within the relationship; setting up regular, joint reviews of expectations and perceptions at both operational and relationship level and working hard to understand what was important for each other.

\section{Interpersonal Relationships}

In order to develop interpersonal relationships at all levels, the interviewees talked about paying careful attention to the processes of engaging the other party and the language used; encouraging a natural approach and shared passion, free from posturing, by acting as a role model themselves. They recognised that dialogue across all levels of the relationship was vital and encouraged it through regular, planned, balanced and two-way meetings. They also worked hard at developing soft skills and continually checked for miscommunication and misinterpretation.

\section{Way of Working}

The interviewees explained that they worked hard to understand not only the culture of the partner organisation but also that of their own. They seemed keen to contribute to the development of processes that would help both organisations jointly assess, improve and vision their relationship both then and in the future. They saw strategic relationships as sources of competitive advantage and focused on finding smart, successful solutions 
together. They sought out opportunities for integrated and collaborative working at all levels. They worked hard to ensure that the way they operated was fair, optimistic, interdependent, open, transparent and adaptable. They tried to anticipate marked improvements in predictability of operating performance and jointly developed appropriate measures. They made a point of setting up matrixed contacts at all levels and invested time and effort in developing relationships both between and within contracts.

\section{Dealing with Problems}

The interviewees contributed to an ethos that ensured that airing of issues and resolution of operational or relational problems became everyone's top priority. They had clear and agreed processes in place for dealing with operational problems before they arose and used them as opportunities to strengthen the relationship through joint exploration of issues and alternatives. They recognised that solutions developed together would lead to better outcomes and greater value for all. Also they were willing to learn from good news as well as bad; and took great care to ensure that solutions were disseminated and good practice shared.

\section{Performance Management}

The interviewees were keen to contribute to the joint development of a mix of hard and soft measures for the relationship, though many of them were unsure quite how to do this. However they were keen to regularly review and more importantly improve both business performance and the quality of the relationship. They planned and acted upon two way reviews built around mutually derived criteria. They tried to measure behaviours as well as operational deliverables sometimes using tailor-made tools to jointly measure, assess and develop their relationships.

\section{ESTABLISHING AND DEVELOPING STRATEGIC RELATIONSHIPS - THE ROLE FOR OPERATIONS MANAGERS}

Our discussions with managers in these exemplary relationships have provided some insight as to how operations managers might go about establishing and developing some of their key strategic relationships. We have captured these as guidelines which could be used by operations managers who are invited, or indeed challenged, to contribute to the creation or development of a strategic relationship. They offer some indication as to what the role would look like if done well. These are presented in Table 6.

Table 6 Establishing and Developing Strategic Relationships - The Role for Operations Managers

\begin{tabular}{|c|c|c|c|}
\hline Stage & Dimension & Elements & Role for Operations Managers \\
\hline \multirow[t]{5}{*}{ Establishing } & \multirow[t]{4}{*}{$\begin{array}{l}\text { Partner } \\
\text { Selection }\end{array}$} & $\begin{array}{l}\text { Business } \\
\text { fit }\end{array}$ & $\begin{array}{l}\text { - Have clear aspirations for the right type of partner and } \\
\text { type of project } \\
\text { - Look for a mutual fit of aspirations, objectives, vision, } \\
\text { values and culture. }\end{array}$ \\
\hline & & Mind set & $\begin{array}{l}\text { - Commit to a long term relationship through good and } \\
\text { ill. }\end{array}$ \\
\hline & & Criteria & $\begin{array}{l}\text { - Explore technical, commercial, cultural and } \\
\text { behavioural issues and select on values, ethos and } \\
\text { culture. }\end{array}$ \\
\hline & & Process & $\begin{array}{l}\text { - Support selection guidelines with rigorous tools and } \\
\text { processes. }\end{array}$ \\
\hline & Nature of the & Fit & - Check whether the contract is parity-based, mutually \\
\hline
\end{tabular}




\begin{tabular}{|c|c|c|c|}
\hline & Contract & & $\begin{array}{l}\text { developed and that it will support and serve the } \\
\text { relationship over time. }\end{array}$ \\
\hline & & Impact & $\begin{array}{l}\text { - Encourage collaboration up and down the supply } \\
\text { chain to encourage transparency and flexibility. }\end{array}$ \\
\hline & & Risk & $\begin{array}{l}\text { - Always allocate risk to the party most able to manage } \\
\text { it. } \\
\text { - Use transparency and openness to turn risk into a } \\
\text { positive feature. }\end{array}$ \\
\hline & & Detail & $\begin{array}{l}\text { - Favour a light touch with broad headers and take care } \\
\text { to agree measures of both success and behaviour. }\end{array}$ \\
\hline Developing & $\begin{array}{l}\text { Understanding } \\
\text { each Other }\end{array}$ & $\begin{array}{l}\text { Individual } \\
\text { level }\end{array}$ & $\begin{array}{l}\text { - Make the effort to get to know each other's 'wow' } \\
\text { factors and what will 'get up the other guy's nose'. }\end{array}$ \\
\hline & & $\begin{array}{l}\text { Business } \\
\text { level }\end{array}$ & $\begin{array}{l}\text { - Work towards a detailed understanding of each } \\
\text { others' drivers and decision making processes. }\end{array}$ \\
\hline & & Process & $\begin{array}{l}\text { - Set up regular, joint reviews of expectations and } \\
\text { perceptions and work hard to understand what is } \\
\text { important for each other. }\end{array}$ \\
\hline & $\begin{array}{l}\text { Interpersonal } \\
\text { Relationships }\end{array}$ & Approach & $\begin{array}{l}\text { - Model a natural chemistry and shared passion, free } \\
\text { from posturing. }\end{array}$ \\
\hline & & $\begin{array}{l}\text { Communic } \\
\text {-ations }\end{array}$ & $\begin{array}{l}\text { - See dialogue as vital and encourage it through } \\
\text { regular, planned, balanced and two-way meetings. }\end{array}$ \\
\hline & & Process & $\begin{array}{l}\text { - Work hard at developing soft skills and continually } \\
\text { check for miscommunication \& misinterpretation. }\end{array}$ \\
\hline & $\begin{array}{l}\text { Way of } \\
\text { Working }\end{array}$ & Drivers & $\begin{array}{l}\text { - See relationships as sources of competitive } \\
\text { advantage and focus on finding smart, successful } \\
\text { solutions together. }\end{array}$ \\
\hline & & Culture & $\begin{array}{l}\text { - Foster integration, openness, transparency and } \\
\text { collaborative working at all levels. }\end{array}$ \\
\hline & & Impact & $\begin{array}{l}\text { - Look for a marked improvement in predictability which } \\
\text { will be a clear source of competitive advantage. }\end{array}$ \\
\hline & & Process & $\begin{array}{l}\text { - Set up matrixed contacts at all levels and invest in } \\
\text { relationships both between and within contracts. }\end{array}$ \\
\hline & $\begin{array}{l}\text { Dealing with } \\
\text { Problems }\end{array}$ & Approach & $\begin{array}{l}\text { - See problems as opportunities to learn and develop } \\
\text { through joint exploration of issues and alternatives. }\end{array}$ \\
\hline & & Impact & $\begin{array}{l}\text { - Learn from good news as well as bad; develop } \\
\text { solutions together to yield better outcomes and value } \\
\text { for all. }\end{array}$ \\
\hline & & Process & $\begin{array}{l}\text { - Ensure that problems become everyone's top priority; } \\
\text { issues are aired, solutions are disseminated and good } \\
\text { practice is shared. }\end{array}$ \\
\hline & $\begin{array}{l}\text { Performance } \\
\text { Management }\end{array}$ & Emphasis & $\begin{array}{l}\text { - Use two way reviews built around mutually derived } \\
\text { criteria to ensure that what matters is measured, } \\
\text { analysed and act upon. }\end{array}$ \\
\hline & & Mix & - Measure behaviours as well as deliverables \\
\hline & & Process & $\begin{array}{l}\text { - Use tailor-made tools to jointly measure, assess and } \\
\text { develop relationships. }\end{array}$ \\
\hline
\end{tabular}

\section{CONCLUSIONS AND CONTRIBUTIONS}

The objectives of this paper were first to identify, from the literature, the key themes in the management of strategic relationships, second to apply those themes to understand how exemplary organisations establish and develop strategic relationships and third to determine the role of operations managers in this process.

This research has made a number of important contributions for both practitioners and academics. From a theoretical point of view this paper has made three distinct contributions. 
First, we would like to suggest a more precise and detailed definition of strategic relationships. We would suggest that strategic relationships are those business relationships which have long lives, typically across a programme of several projects and activities, with interactions between as well as within the projects. They are characterised by greater parity between the parties and more equal sharing of power than other relationships. The players recognise the synergies - actual and potential, immediate and on-going - that result from working well together over time and are passionate about realising them. They are acutely aware of the kind of people and organisations that they can get on with and are very careful to select who they work with. Although there may be an underpinning contract or set of contracts, the spirit of the relationship dominates the modus operandi. Each party knows exactly what the other is looking for from the relationship and they recognise that the ultimate test of their relationship is how well it holds together when things go wrong. They jointly establish measures of their relationship using them to continually develop and strengthen it over time.

Second, we have proposed the seven dimensions as an overarching framework that encapsulates and organises the many criteria that are found in the literature to describe strategic relationships.

Third, we have identified 24 elements of the seven dimensions and provided examples of each element to facilitate greater understanding of the ways in which strategic business relationships can be both established and developed.

From a practitioner perspective the outputs from our research have been summarised into a number of guidelines which flesh out the role for operations managers looking to identify, establish, evaluate or strengthen their role in establishing and developing strategic business relationships. It has also provided a clear indication of what the OM role would look like if carried out in the spirit of an exceptional relationship.

This research has a number of inherent weaknesses in particular the interpretative nature of the analysis. One important issue was that the interviews were only carried out with the organisation recommended for having exemplar relationships and not with both parties to that relationship. In order to study relationships both parties should ideally be interviewed since the 'relationship' is jointly held, established and developed, and, additionally, the opinions held by one party may not be the same as the other.

Further, the study was conducted in one sector, though a range of types of organisations were involved. More research is now needed to test the outcomes on a wider set of sectors and organisations, and involving both parties to the relationship. We also focussed, albeit intentionally, on strategic relationships in our search for exemplars to emulate. We intentionally ignored poor practice and transactional relationships. It might also be helpful to research more into transactional relationships in order to identify the differences in managing them versus strategic relationships and even to create an instrument for helping organisations assess the nature and status of their relationships. Future work might test, develop and extend the content within the frameworks provided and test its validity in other sectors. It might also look at the specific circumstances under which OM might be the leader, the convenor, or an equal in the relational arena. What would operations managers need to be good at in each circumstance? How would the role for operations managers need to be re-conceptualised?

We hope that our findings will provide some guidance to OM professionals who are invited or challenged to contribute to the performance of an organisation choosing to establish or develop one or more strategic relationships and also to provide a stimulus for further operations management research in this area. 


\section{ACKNOWLEDGEMENTS}

The authors would like to express their appreciation to Adrian McLean of McLean and George Ltd for his insightful comments and suggestions on earlier drafts of this paper.

We would also like to thank the two anonymous referees for the helpful guidance in the development of this paper.

We are greatly indebted to the many managers who gave up their time to take part in this study and for sharing their views with us.

\section{REFERENCES}

Bennett, J. and Jayes S., (1995), Trusting the Team, Reading Construction Forum, London Bennett, J. and Jayes S., (1998), The Seven Pillars of Partnering, Reading Construction Forum, London

Black, C., Akintoye A., Fitzgerald E., (2000), "An analysis of success factors and benefits of partnering in construction", International Journal of Project Management, 18 (6) 423-434

Blois, K.J., (1999) "Trust in Business to Business Relationships: An Evaluation of its Status", Journal of Management Studies, 36 (2) 197-215

Boddy, D., and Macbeth D., (2000), "Prescriptions for management change: a survey of their effects in projects to implement collaborative working between organisations", International Journal of Project Management, 18 (5) 297-306

Bresnen M., (1996), "An organizational perspective on changing buyer-supplier relations: a critical review of the evidence", Organization, 3 (1) 121-146

Bresnen, M., (2007), "Deconstructing partnering in project-based organisation: Seven pillars, seven paradoxes and seven deadly sins", International Journal of Project Management, 25 (4) 365-374

Bresnen, M., and Marshall N., (2000), "Partnering in construction: a critical review of issues, problems and dilemmas", Construction Management \& Economics, 18 (2) 229-237

Bresnen, M., and Marshall N., (2002), "The engineering or evolution of co-operation? A tale of two partnering projects", International Journal of Project Management, 20 (7) 497-505

Buffa, E. S., (1976), Operations Management: The Management of Productive Systems, Wiley, New York

Celuch, K. G., Bantham J. H., Kasouf C. J., (2006), "An Extension of the marriage metaphor in buyer-seller relationships: An exploration of individual level process dynamics, Journal of Business Research, 59 (5) 573-581

Cooperrider, D.L., and Srivastva S., (1997), "Appreciative Inquiry in Organizational Life", Research in Organizational Change and Development, 1 129-169

Cooperrider, D.L., and Whitney D., (2005), Appreciative Inquiry: A Positive Revolution in Change, Berrett-Koehler

Coughlan, P., Coghlan D., Lombard F., Brennan L., McNichols T., Nolan R., (2003), "Managing collaborative relationships in a period of discontinuity", International Journal of Operations and Production Management; 23 (10) 1246-1259

Cousins, P. D., (2005), "The alignment of appropriate firm and supply strategies for competitive advantage", International Journal of Operations and Production Management, 25 (5) 403-428

Cowan C., Gray C., and Larson E., (1992), "Project Partnering", Project Management Journal, 22 (4) 5-11

Doz Y..L., and Hamel G.,(1998), Alliance Advantage: The Art of Creating Value through Partnering, Harvard Business School Press, Massachusetts

Dwyer, F. R.; Schurr P.H., and Oh S., (1987), "Developing Buyer-Seller Relations", Journal of Marketing, 51 (2) 11-28 
Dyer, J.H., (1997), "Effective Interfirm Collaboration: How Firms Minimize Transaction Costs and maximize Transaction Value", Strategic Management Journal, 18 (7) 535-556

Easton G., (2002), "Industrial networks: a review", in Ford D., (ed.) Understanding Business Marketing and Purchasing, $3^{\text {rd }}$ ed., Thomson Learning, London, 123-144

Easton G., and Araujo L., (1985), "The network approach: an articulation", $2^{\text {nd }}$ Open IMP International Research Seminar, University of Uppsala, September

Egan J., (1998) Rethinking Construction, Department of the Environment, Transport and Regions, London

Evans, J.R., and Berman B., (2001), "Conceptualizing and Operationalizing the Business-toBusiness Value Chain", Industrial Marketing Management, 30, (2) 135-148

Fitzsimmons, J. A. and Fitzsimmons M. J., (2006) $5^{\text {th }}$ ed., Service Management, McGrawHill, New York

Ford. D., Gadde L-E., Håkansson H., Snehota I., (2003), Managing Business Relationships, 2nd ed., Wiley, Chichester

Fynes, B., Voss C., de Búrca S., (2005), "The impact of supply chain relationship dynamics on manufacturing performance", International Journal of Operations and Production Management; 25 (1) 6-19

Gardner, J., and Cooper M.C., (1988), "Elements of Strategic Partnerships", in McKeon J.E., (ed.), Partnerships: A Natural Evolution in Logistics, Results and Proceedings of the 1988 Logistics Resource Forum, Leaseway Transportation Corporation and The Ohio State University, Cleveland, 15-31

Giannakis, M., (2008), Facilitating learning and knowledge transfer through supplier development, Supply Chain Management 13 (1) 62-72

Gill, J., and Butler R.J., (2003), "Managing Instability in Cross-Cultural Alliances", Long Range Planning, 36, (6) 543-564

Giunipero, L., Handfield R.B., Eltantawy R., (2006), "Supply management's evolution: key skill sets for the supply manager of the future", International Journal of Operations and Production Management; 26 (7) 822-844

Goold, M., and Campbell A., (2003), "Structured Networks: Towards the Well-Designed Matrix", Long Range Planning, 36 (5) 427-439

Gulati, R., (1998), "Alliances and Networks", Strategic Management Journal, 19, (4) 293-317

Håkansson H., and Snehota I., (2002), "Analysing business relationships" in Ford D., (ed.) Understanding Business Marketing and Purchasing, $3^{\text {rd }}$ ed., Thomson Learning, London, 162-182

Henderson, J.C., (1990), "Plugging into Strategic Partnerships: The Critical IS Connection", Sloan Management Review, 31 (3) 7-18

Howard, M., and Squire B., (2007) "Modularization and the impact on supply relationships", International Journal of Operations and Production Management, 27 (11) 1192-1212

Hutt, M.D., Stafford E.R., Walker B.A., Reingen P.H., (2000), "Defining the Social Network of a Strategic Alliance", MIT Sloan Management Review, 41 (2) 51-62

Johnston, D.A., McCutcheon D.M., Stuart F.I., and Kerwood H., (2004), "Effects of supplier trust on performance of cooperative supplier relationships", Journal of Operations Management, 22 (1) 23-38

Kalwani, M.U.; and Narakesari N., (1995), "Long-term Manufacturer-Supplier Relationships: Do They Pay Off for Supplier Firms?", Journal of Marketing, 59 (1) 1-16

Kanter, R.M., (1994), Collaborative Advantage, Harvard Business Review, 72 (4) 96-108

Kelly M.J., Schaan J-L., and Joncas H., (2002), "Managing alliance relationships: Key challenges in the early stages of collaboration, R\&D Management, 32 (1) 11-22

Koza, M.P. and Lewin A.Y., (1998), "The co-evolution of strategic alliances", Organization Science, 9 (3) 255-264

Larson, E., (1995), "Project Partnering: Results of Study of 280 Construction Projects", Journal of Management in Engineering, 11 (2) 30-35

Latham, M., (1994), Constructing the team, Department of the Environment, London

Lorenzoni, G., and Baden-Fuller C., (1995), "Creating a Strategic Center to Manage a Web of Partners", California Management Review, 37 (3) 146-163 
Lorenzoni, G., and Lipparini A., (1999), "The Leveraging of Interfirm Relationships as a Distinctive Organisational Capability: A Longitudinal Study", Strategic Management Journal, 20 (4) 317-337

Mohr, J., and Spekman R., (1994), "Characteristics of Partnership Success: Partnership attributes, communication behaviour, and conflict resolution techniques", Strategic Management Journal, 15 (2) 135-152

Monczka, R.M., Trent R., and Handfield R., (2004), Purchasing and Supply Chain Management, 3rd ed., Southwestern College Publishing, Cincinnati, Ohio

Morgan, R.M., and Hunt S.D., (1994), "The Commitment-Trust Theory of Relationship Marketing", Journal of Marketing, 58 (2) 20-38

Naudé, P., and Turnbull P.W., (1998), Network Dynamics in International Marketing, Elsevier Science, Oxford

Phua F.T.T., and Rowlinson S., (2003), "Cultural differences as an explanatory variable for adversarial attitudes in the construction industry: the case of Hong Kong", Construction Management \& Economics, 21 (7) 777-785

Robicheaux, R. A., and Coleman J.E., (1994), "The structure of marketing channel relationships", Journal of the Academy of Marketing Science, 22 (1) 38-51

Roxenhall T., and Ghauri P., (2004), "Use of the written contract in long-lasting business relationships", Industrial Marketing Management, 33, 261-268

Shaw P., (2002), Changing Conversations in Organisations. A complexity approach to change, Routledge, London

Sleuwaegen, L., Schep K., den Hartog G., and Commandeur H., (2003), "Value creation and the alliance experiences of Dutch companies", Long Range Planning, 36 (6) 533-542

Spekman, R.E., Forbes T.M., Isabella L.A., and MacAvoy T.C., (1998), "Alliance management: a view from the past and a look at the future", Journal of Management Studies, 35 (6) 747-742

Stafford E.R., (1994), "Using Co-operative Strategies to Make Alliances Work", Long Range Planning, 27 (3), 64-74

Staughton, R., and Johnston R., (2005), "Operational Performance Gaps in Business Relationships", International Journal of Operations and Production Management, 25 (4) 320-332

Taylor, A., (2005), "An operations perspective on strategic alliance success factors", International Journal of Operations and Production Management, 25 (5) 469-490

Turnbull P., Ford D., and Cunningham M., (2002), "Interaction, relationships and networks in business markets: an evolving perceptive" in Ford D., (ed.) Understanding Business Marketing and Purchasing, $3^{\text {rd }}$ ed., Thomson Learning, London, 3-18

Wild, R., (1980), Production and Operations Management, Holt, Rinehart and Winston, London

Williamson, O. E., (1996), "Economic Organization: The case for candor", Academy of Management Review, 21 (1) 48-57

Williamson, O.E., (2008), "Outsourcing: Transaction cost economics and supply chain management", Journal of Supply Chain Management, 44 (2) 5-16

Wilkinson I.F., and Young L.C., (2002), "Business dancing - the nature and role of interfirm relations in business strategy", in Ford D., (ed.) Understanding Business Marketing and Purchasing, $3^{\text {rd }}$ ed., Thomson Learning, London, 107-119

Wuyts, S. H. K., and Geyskens I., (2005), "The Formation of Buyer-Supplier Relationships: Detailed Contract Drafting and Close Partner Selection", Journal of Marketing, 69 (4) 103-117 